\title{
Leitura e análise
} de imagem

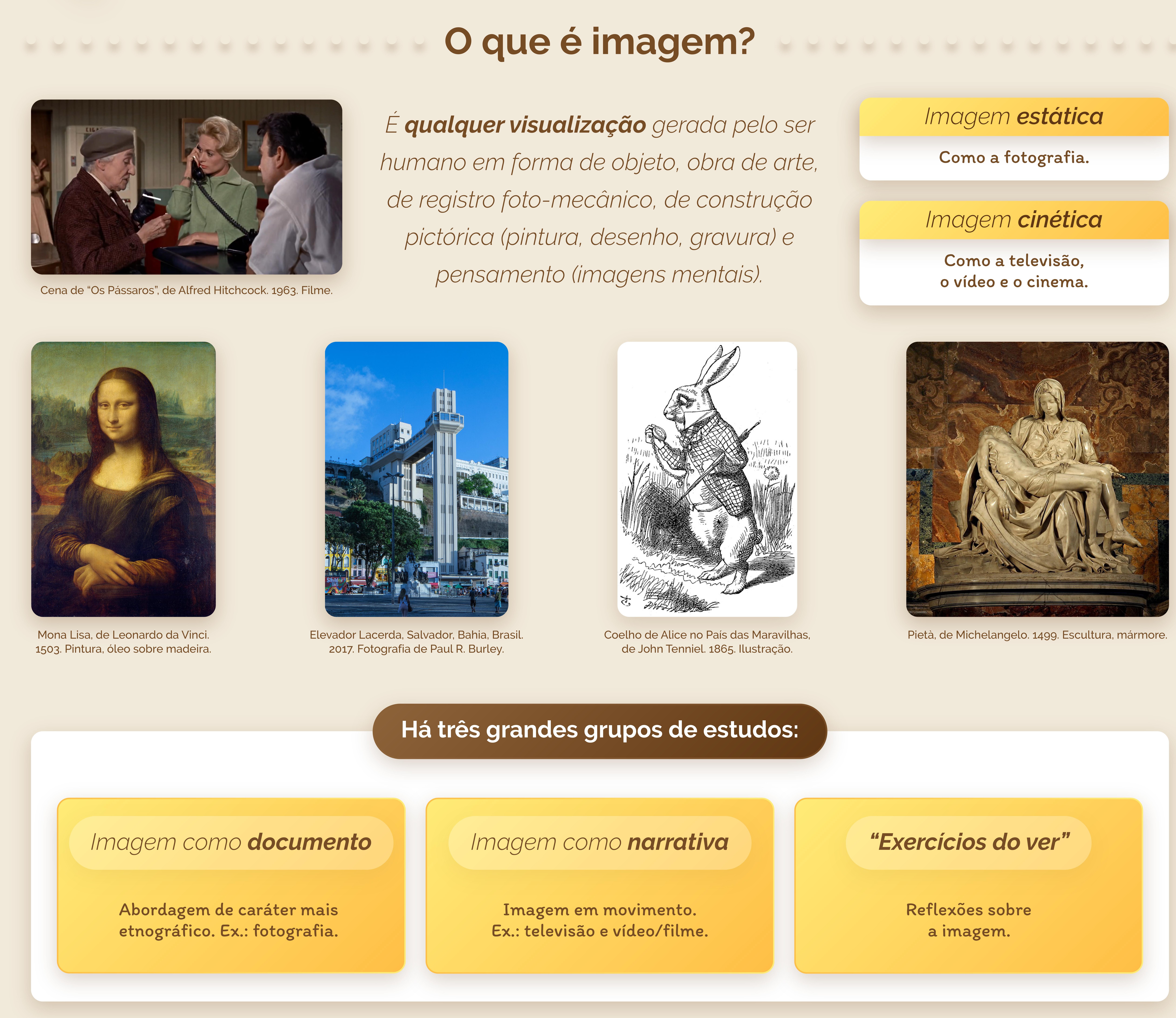

Análise de imagem

1 Leitura $\rightarrow 2$ Interpretação $\rightarrow 3$ Sintese/conclusão
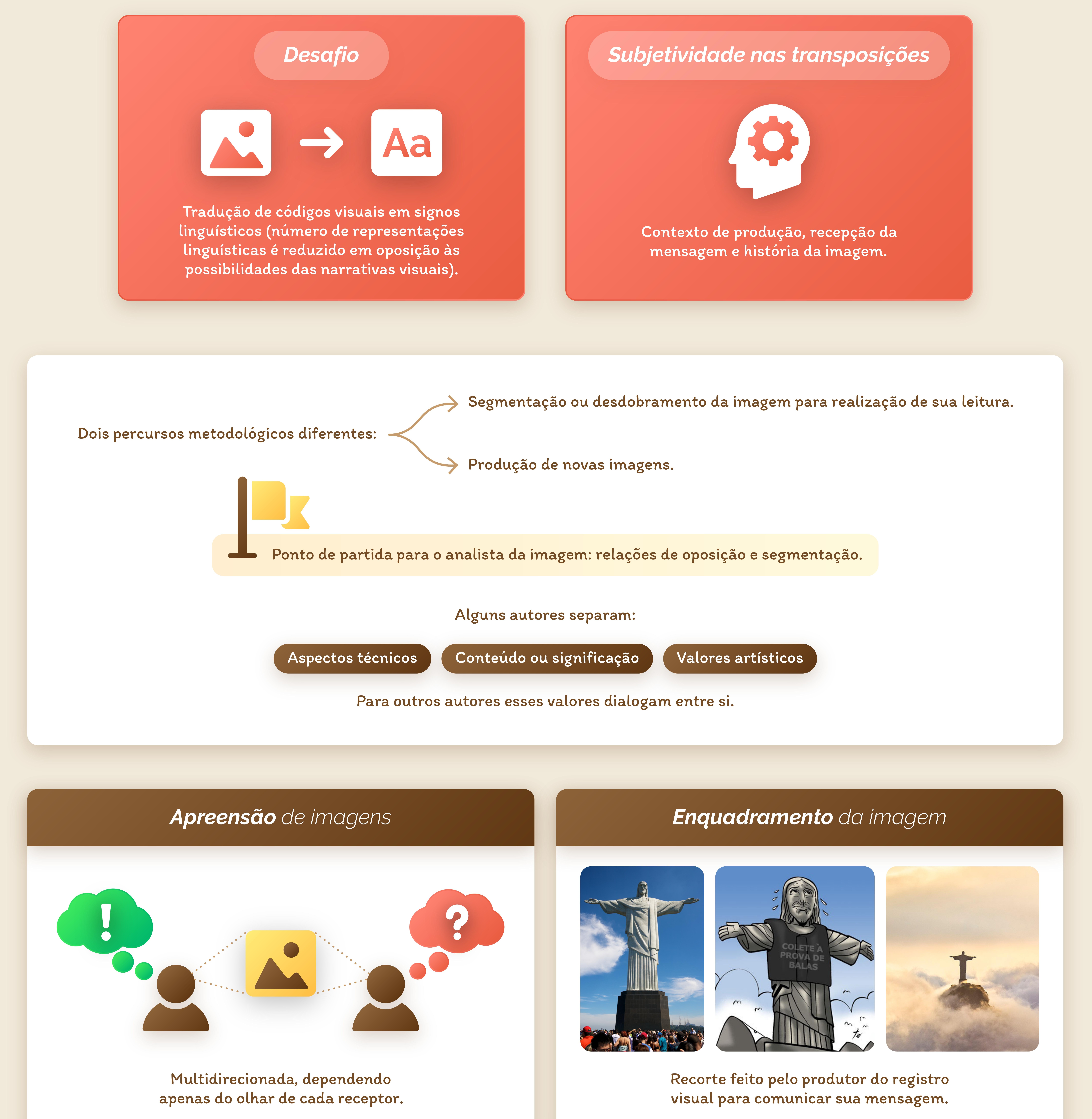

Multidirecionada, dependendo
apenas do olhar de cada receptor.

Recorte feito pelo produtor do registro
visual para comunicar sua mensagem.

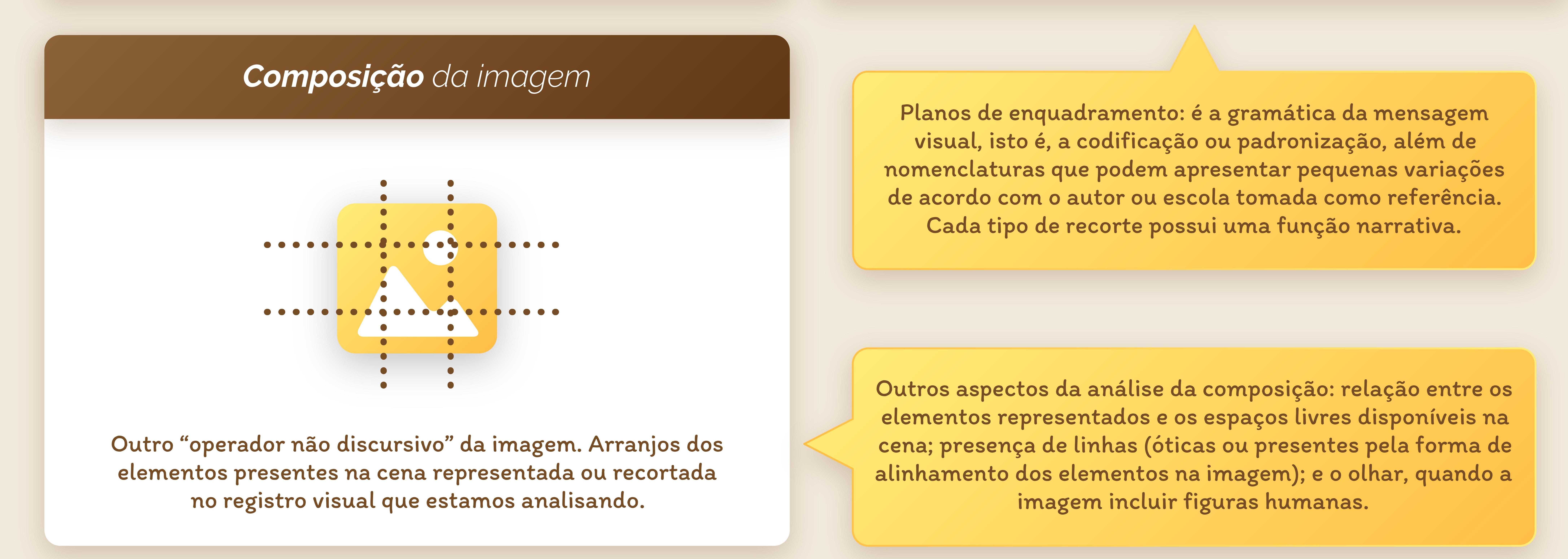

O que pode ser analisado?

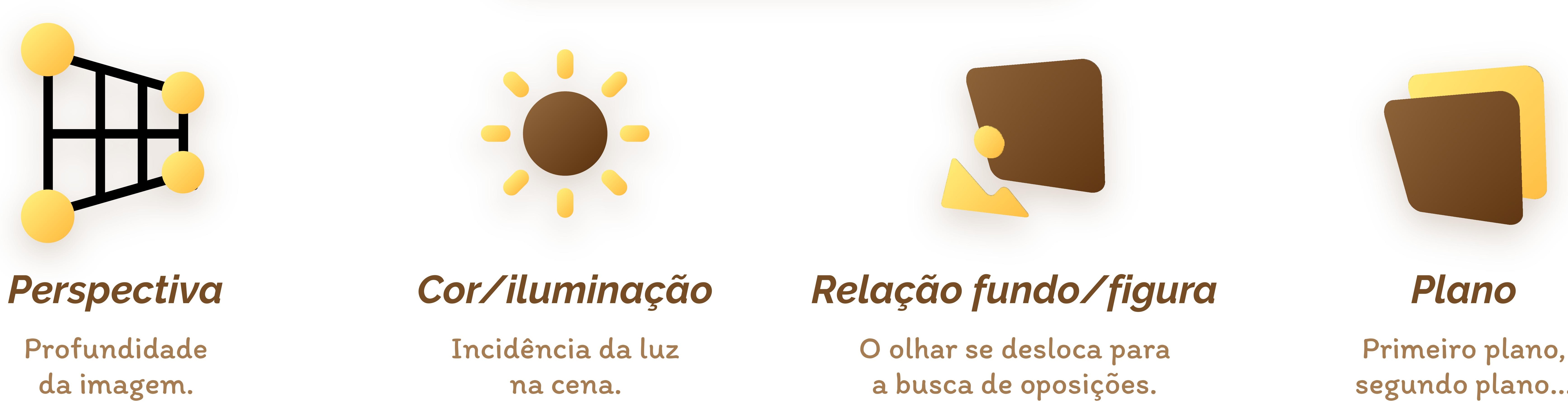
象
ib 19
Posição do registrador
Produção e recepção
Altera a leitura
da imagem.

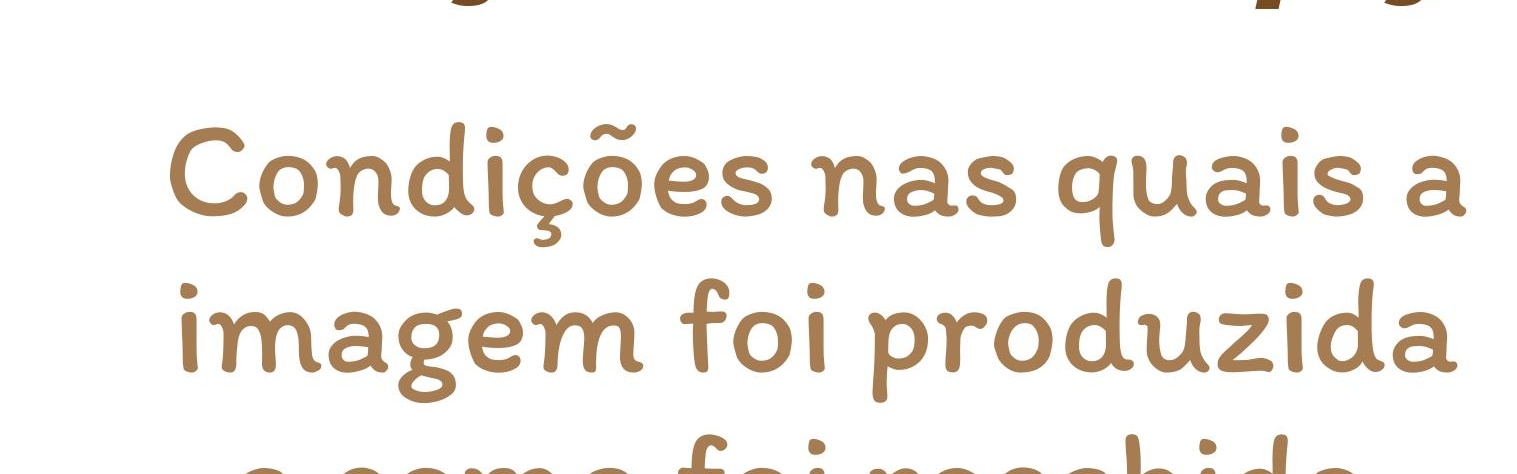

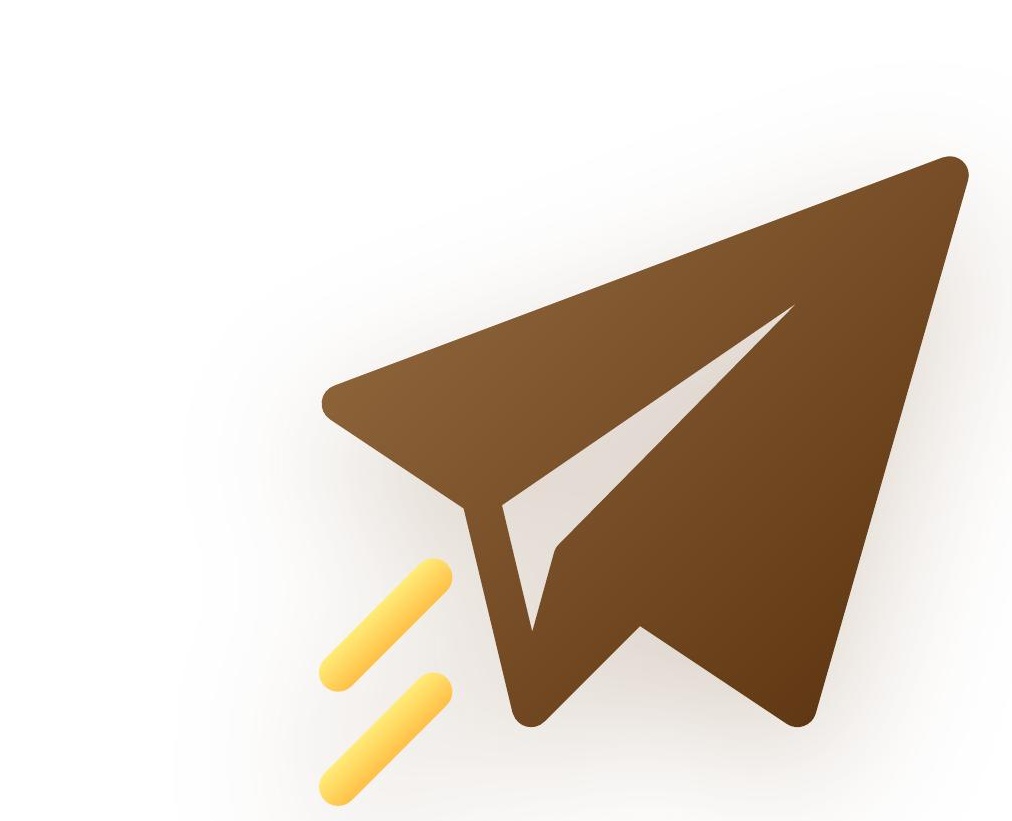
Meio
Meios de comunicação em
que se enserea menssagem
visual analisada

Em imagens cinéticas, pode-se analisar aspectos temporais (tempo de duração): 